\title{
The structure of food demand in urban city of Nigeria: An application of a Linearized Almost Ideal Demand System (LA/AIDS)
}

\author{
E. J. Udoh ${ }^{1 \star}$, E. R. Mbossoh ${ }^{1}$, E. S. Udoh ${ }^{2}$ and S. B. Akpan ${ }^{2}$ \\ ${ }^{1}$ Department of Agricultural Economics and Extension, University of Uyo, Uyo, Akwa lbom State, Nigeria. \\ ${ }^{2}$ Department of Agricultural Economics and Resources Management, Akwa Ibom State University, Mkpat-Enin, \\ Akwa Ibom State, Nigeria. \\ Accepted 4 December 2012
}

\begin{abstract}
Household-level micro data were fitted on Linearized Almost Ideal Demand System (LA/AIDS) model to estimate the structure of starchy, animal protein, plant protein and fatty foods demand in Uyo Metropolis of Akwa Ibom State, Nigeria. Panel data used in this study came from four months household food consumption survey. Thirty responding households were randomly selected for the data collection. Estimates of LA/AIDS revealed that the budget shares of different food sub-groups for the sample households responded significantly to changes in the household size, marital status, household's head education and income levels. Using a system of equations, the estimated expenditure elasticity revealed that starchy and animal protein foods had expenditure elasticity less than zero which implies that, they are "necessity" goods; while plant protein and fat food items were "luxuries". Also, the estimated own-price elasticity coefficients were negative indicating that as the prices of each food group increase, the relative share of household expenditure decrease accordingly. Cross-price elasticity coefficients for some food groups were negative indicating they are "complementarities", while others have positive coefficients suggesting they are "substitutes". Based on findings from this study, recommendations to increase demand for these food groups are made.
\end{abstract}

Key words: Household, demand, linearized almost ideal demand system (LA/AIDS), Uyo, elasticities.

\section{INTRODUCTION}

For better growth and development, an average man needs to consume adequate quantities of different food items in the right proportions. This is referred to as "the balanced diet". Carbohydrate, protein, fats and oil, vitamins, minerals and water are the classes of food that constitute a balanced diet and which when consumed provides the body with energy, growth, development and repairs. The place of food in supplying nutrients to the growing population cannot be over emphasized, and depending on the income of the households, demand and

${ }^{*}$ Corresponding author. E-mail: ej_udoh@hotmail.com. Tel: +234 (0) 7037383531 . consumption of food classes differ. While some food items are price and income elastic, others are inelastic. The general economic welfare challenges facing most Nigerian urban households affect the demand and subsequent consumption of these food items, and as a result poor households tend to demand more of starchy foods and less of protein food (FAO, 1980; Akintola and Udoh, 2002). The demand for food as it is the case for any other commodity depends on a number of factors which include income, own-price, consumer preferences, and prices of other substitutes. Demographic factors, such as changes in household size and in the age distribution of the population, can bring about changes in consumption demand for food drives production, and therefore stands out that, the more food item that is 
demanded; the more its production is encouraged.

An evaluation of the demand function for food items is very important, and needs immediate attention. Empirical studies on food demand among consumers in major Nigerian cities had received low priority among researchers even in the face of rising food demand and deficit domestic supply. This issue is further compounded by the increasing food insecurity and the geometric rise in the population of the country. The food demand function can be estimated from maximizing the utility function subject to budgetary behaviour of the consumer, in that the consumer maximizes utility from consumption, given income and the market prices of the commodity. There are various algebraic specifications of the demand system, and these include: the Linear and Quadratic Expenditure Systems, the Rotterdam model, Translog model, the Working model, and the Linearized Approximated Almost Ideal Demand System (LA/AIDS) (Taljaard et al., 2003).

The LA/AIDS model has become a choice model for many applied demand analyses, since its introduction by Deaton and Meulbauer in late 1970s. The model is the most favoured in demand analysis because it is flexible, avoids nonlinear estimation and allows for estimation of price, expenditure, income and cross price-elasticities. It also allows for wider range of variables to be included in the household demand modeling (Glewwe, 2001; Barnett and Seek, 2008). Besides, its application could be of interest especially in Akwa lbom State where food demand analyses are uncommon. The rationale for this research is that very few economic researches have been conducted on estimation of food demand in Uyo metropolis. As a result, it can be said that estimates for food demand elasticities needed for demand projections for food items do not exist in the metropolis for many products. Hence efficient economic policy on food demand in the state which is hinged on the availability of reliable food demand function estimates could be jeopardized. Therefore, this study is basically aimed at estimating staple food demand parameters in Uyo metropolis in Akwa Ibom state. The estimated elasticities can be used to measure the impact of agricultural policies and to predict the future consumption in the context of food security in terms of access, availability, stability and food quality.

\section{METHODOLOGY}

\section{Study area}

The research was conducted in Uyo Metropolis, in Uyo local government area of Akwa lbom State. Uyo is one of the 31 local government areas of Akwa Ibom State. It is centrally located and lies between latitude $5.05^{\circ} \mathrm{North}$ and longitude $80^{\circ}$ East within the equatorial rainforest belt. Uyo has a dual status as a state capital and a local government headquarters. It is bounded by Abak, Itu, Uruan, Ibesikpo Asutan and Etinan local government areas. Uyo has a population of 309,573 , consisting of 153,113 males and156,460 females (National Population Commission, 2006).

\section{Sampling size and sampling procedure}

A Multi-stage random sampling procedure was used to select households from different streets in Uyo Metropolis. First, five streets were randomly sampled among major streets in Uyo metropolis. The streets were Abak road, Nwaniba road, lkot Ekpene road, Aka road and Ikpa road. The second stage involved a systematic sampling of six households in each of the selected street using sampling interval of 10 . A total of 30 households were selected in this study area for data collection. The selected households were visited once weekly and consistently for a period of 16 weeks. We choose this period to enable the sampled households to express fully the demand pattern for all listed food groups.

\section{Aids model specification}

According to Deaton and Muellbauer (1980), the AIDS model is usually specified as:

$W_{i}=\alpha+\sum_{i}^{n} \gamma_{i j n} \operatorname{Ln} P_{j}+\beta_{i} \operatorname{Ln}(X / P)+\mu_{i} \quad \mathrm{i}=1, \ldots, \mathrm{n}$

where, $\mathrm{W}_{\mathrm{i}}$ is the budget share of the $\mathrm{i}^{\mathrm{t}}$ good (that is, $W_{i}=P_{i} Q_{i} / X$ ); $P_{j}$ is the weighted average price of items in group $j^{\text {th }} ; X$ is the total expenditure on the group of goods being analyzed; $\mu_{t}$ is the random error term; $P$ is the translog price index of group of goods being analyzed and is defined as:

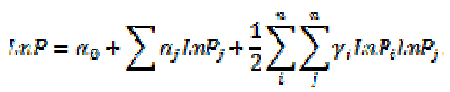

When Equation (2) is integrated into Equation (1), the system becomes non-linear, thus complicating the estimation process. To overcome this problem, the Stone's price index defined in Equation (3) was used instead of the translog price index in Equation (1) according to Deaton and Meulbauer (1980) and Sasaki (1993).

$\operatorname{Ln} P^{*}=\sum_{i=1}^{n} W_{i} \operatorname{Ln} P_{i}$

The resultant model is called Linearized Approximate AIDS Model (LA/AIDS) (Blanciforti et al., 1986; Wessells et al., 1997; Balcombe et al., 2003; Jeffry and Brown, 2008). The substitution of the Stone's price index for the translog price index causes a simultaneity problem, because the dependent variable $\left(\mathrm{W}_{\mathrm{i}}\right)$ also appears on the right-hand side of the LA/AIDS model (Eales and Unnevehr, 1988). To eliminate this problem, we replaced $W_{i}$ in equation 3 with its predicted value $W^{*}$ which is then inserted into equation 4 yielding the unbiased LA/AIDS expressed as:

$W_{i}=\alpha_{i}+\sum_{j}^{n} \gamma_{i j} \operatorname{Ln} P_{j}+\beta_{i}\left(\operatorname{LnX}-\sum_{i=1}^{n} W^{*} \operatorname{Ln} P_{i}\right)+\mu_{i} \ldots$

Equation 4 was further transformed by incorporating the socioeconomic characteristics of responding households into it. The resulting Equation (5) was then applied to the empirical data, and the estimated parameters were used to calculate the required elasticities and also to represent the effect of socio-economic characteristics of respondents.

$W_{i}=\alpha_{i}+\sum_{j}^{n} \gamma_{i j} \operatorname{Ln} P_{j}+\beta_{i}\left(\operatorname{Ln} X-\sum_{i=1}^{n} W^{*} \operatorname{Ln} P_{i}\right)+\sum \varphi V+\mu_{i}$ 
Table 1. AIDS model for household demand for starchy food in Uyo metropolis (budget share for starchy food).

\begin{tabular}{lccc}
\hline Variable & Coefficient & Standard error & t-value \\
\hline Constant & 0.006 & 0.029 & 0.207 \\
Sex & 0.005 & 0.005 & 1.016 \\
Age & 0.001 & 0.000 & 1.383 \\
Marital status & 0.000 & 0.003 & -0.097 \\
Education & 0.001 & 0.001 & 0.945 \\
Household size & 0.093 & 0.032 & $2.909^{\star *}$ \\
Household income & $-0.024 \mathrm{e}-08$ & 0.008 & $-2.735^{\star * *}$ \\
Effect of real income $\left(\beta_{i}\right)$ & $-0.047 \mathrm{e}-05$ & 0.009 & $-5.000^{* * *}$ \\
Weighted unit price of starchy food $\left(\mathrm{Vij}_{\mathrm{ij}}\right)$ & 0.084 & 0.019 & $4.353^{\star * *}$ \\
$\mathrm{R}^{2}$ & 0.768 & & \\
F statistics & $8.701^{\text {***}}$ & & \\
\hline
\end{tabular}

${ }^{* *}$, and ${ }^{* * *}$ represent 5 and $1 \%$ levels of significance. Source: Results from LA/AIDS model.

From $\mathrm{j}=1 \ldots 4$ differentiated food item classes. In this study, the four food classes were starchy food; animal protein; plant protein; fats and oil. $\alpha_{i}=$ average value of the budget share of food items; $\beta_{i}=$ effect of real income on the budget share of the food items; $\gamma_{i j}$ $=$ effect of the prices of items in group $\mathrm{i}^{\text {th }}$ on the budget share of item $\mathrm{i}^{\text {th }} \varphi=$ coefficients of household socio-economic variables; $\mathrm{V}=$ vector of socio-economic variables of responding households defined as follows: Sex $=$ dummy variable $($ male $=1$ and female $=$ 0 ); Age = age of household head measured in years; HHS = household size measured in numbers; Marital status = dummy variable (married $=1$ and unmarried $=0$ ); Education = years spent in formal education by the household head; Income = household's head income measured in naira ( $\mathbb{A})$; Other variables are as defined previously in Equations (1) to (4).

Following the above specifications, the expenditure, own-price and cross-price elasticities of demand for the four groups of food were computed using the estimated parameters of the LA/AIDS model. The close approximate formulae for computing coefficients of elasticity for the food groups are given by Equation (6), (7) and (8) respectively (Jabarin and Al-Karablieh, 2011; Adejobi et al., 2009; Taljaard et al., 2003 and Abdulai and Jain, 1999).

Expenditure elasticity:

$\left(E_{i j}\right)=1+\left\{\frac{\beta_{i}}{w_{l}}\right\}$

Own-price elasticity

$\left(E_{i j}\right)=\frac{\gamma_{i j}}{w_{i}}+\left(\beta_{i}-1\right)$

Cross - price elasticity

$\left(E_{i j}\right)=\left(\frac{V_{i j}}{W_{i}}\right)-\left(\frac{\beta_{i} w_{j}}{w_{j}}\right)$

\section{RESULT AND DISCUSSION}

The result of the estimation of LA/AIDS model as specified in equation (5) for the starchy food is shown in Table 1 . The diagnostic tests revealed the $\mathrm{R}^{2}$ value of 0.768 , which implies that about $76.80 \%$ of total variability in the budget share of starchy food is jointly explained by the specified independent variables in the model. The $\mathrm{F}$ statistic of 8.701 is statistically significant at $1 \%$ probability level; this means that the $R^{2}$ is significant. This result attests to the overall goodness of fit of the LA/AIDS specified regression model.

The empirical results in Table 1 showed that the household size, household's income, effect of real income, weighted unit price of starchy food are significant variables that affect the budget share of starchy food among responding households in this study area. The budget share of starchy food has a positive inelastic relationship with the respondent's household size and weighted unit price of starchy food. This implies that $10 \%$ increase in the household size and weighted unit price of starchy food would lead to a less than $10 \%$ increase in budget share of starchy food. Also, a $10 \%$ increase in the household's income level and effect of real income would lead to a less than proportionate increase in the budget share of household demand for starchy food. This result with respect to household size and income appearing as important demand shifters collaborates the finding of Akintola and Udoh (2002).

Table 2 shows the estimates of LA/AIDS model for plant protein food. The $\mathrm{R}^{2}$ explains about $92.40 \%$ of total variation in the budget share of protein food that is attributed to the specified independent variables in the model. The $F$ statistic of 31.70 is statistically significant at $1 \%$ probability level; this means that the estimated $R^{2}$ is statistically significant. The empirical result showed that marital status, household size, household income level, effect of real income on the budget share of plant protein food $\left(\beta_{\mathrm{i}}\right)$ and weighted unit price of plant protein $\left(\gamma_{i j}\right)$ were statistically significant and had positive inelastic relationships with the budget share of household demand for plant protein foods. The results imply that $10 \%$ increase in these variables would result in a less proportionate 10\% increase in the dependent variable.

Table 3 revealed the estimates of LA/AIDS model for animal protein food in this study area. The diagnostic 
Table 2. LA/AIDS model for household demand for plant protein foods on Uyo Metropolis (budget share for plant protein food).

\begin{tabular}{lccc}
\hline Variable & Coefficient & Standard error & t-value \\
\hline Constant & -0.064 & 0.037 & $-1.725^{\star}$ \\
Sex & 0.002 & 0.009 & 0.273 \\
Age & $-9.814 \mathrm{e}-05$ & 0.001 & 0.147 \\
Marital status & 0.014 & 0.005 & $2.752^{* \star *}$ \\
Education & 0.013 & 0.009 & 1.391 \\
Household size & 0.006 & 0.001 & $4.214^{\star \star *}$ \\
Income & $0.028 \mathrm{e}-08$ & 0.009 & $2.968^{\star \star \star}$ \\
Effect of real income $\left(\beta_{\mathrm{i}}\right)$ & 0.009 & 0.002 & $3.625^{\star \star *}$ \\
Weighted unit price of plant protein $\left(\mathrm{V}_{\mathrm{ij}}\right)$ & 0.000 & 0.000 & $12.707^{\star \star *}$ \\
$\mathrm{R}^{2}$ & 0.924 & & \\
F statistics & $31.703^{\star * *}$ & & \\
\hline
\end{tabular}

*, and ${ }^{* * *}$ represent 10 and $1 \%$ levels of significance. Source: Results from LA/AIDS model.

Table 3. LA/AIDS model for household demand for animal protein foods in Uyo metropolis (budget share for animal protein food).

\begin{tabular}{lccc}
\hline Variable & Coefficient & Standard error & t-value \\
\hline Constant & -0.194 & 0.139 & -1.392 \\
Sex & 0.035 & 0.034 & 1.024 \\
Age & 0.000 & 0.002 & 0.099 \\
Marital status & 0.008 & 0.018 & 0.457 \\
Education & 0.016 & 0.006 & $2.779^{* * *}$ \\
Household size & -0.084 & 0.014 & $-5.971^{* * *}$ \\
Income & $0.126 \mathrm{e}-07$ & 0.068 & $1.865^{\star}$ \\
Effect of real income $(\beta i)$ & -0.002 & 0.001 & $-1.738^{*}$ \\
Weighted unit price of animal protein $\left(\mathrm{Y}_{\mathrm{ij}}\right)$ & $0.036 \mathrm{e}-05$ & 0.011 & $3.374^{* * *}$ \\
$\mathrm{R}^{2}$ & 0.569 & & \\
F statistics & $3.470^{\star * *}$ & & \\
\hline
\end{tabular}

${ }^{*}$ and ${ }^{* * *}$ represent 10 and $1 \%$ levels of significance; Source: Results from LA/ AIDS model.

tests revealed that the $\mathrm{F}$ - statistic was significant at $1 \%$, and this showed the overall correctness and fitness as well as the significance of $R^{2}$ in the estimated model. The $R^{2}$ however indicates that, explanatory variables in the model explain about $56.90 \%$ of total adjusted variation in the budget share of household income that is spent on animal protein food. However, the size of the $R^{2}$ is moderate, which indicates that other important determinants of budget share spent on animal protein food may not capture in the model.

The slope coefficients of education, household income level and weighted price of animal protein are positive and significant determinants of the share of household budget spent on animal protein food. On the other hand, the household size and effect of real income $\left(\beta_{i}\right)$ had negative inelastic relationships with the dependent variable. This implies that, $10 \%$ increase in the household size and effect of real income $\left(\beta_{\mathrm{i}}\right)$ would lead to a less than proportionate increase in the dependent variable. Also, $100 \%$ increase in the education, household income level and weighted price of animal protein would lead to a less than proportionate increase in the budget share for animal protein food. Table 4 showed the estimates of LA/AIDS model for fatty food in this study area. The diagnostic statistics revealed that the F statistic (5.30) was significant at $1 \%$, and this showed the overall goodness of fit as well as the significance of $R^{2}$ in the estimated equation. The $R^{2}$ of 66.9 indicates that, explanatory variables in the model explains about $66.90 \%$ of total adjusted variation in the budget share of household income that is spent on fatty food.

The empirical results showed that education of household head, the real income on the budget share of fatty food items and weighted price of fatty food have positive significant impact on the budget share of fatty food out of the total food expenditure. The results reveal 
Table 4. LA/AIDS model for household demand for fat foods in Uyo metropolis.

\begin{tabular}{lccc}
\hline Variable & Coefficient & Standard error & t-value \\
\hline Constant & -0.059 & 0.088 & -0.667 \\
Sex & 0.004 & 0.020 & 0.209 \\
Age & 0.000 & 0.001 & -0.167 \\
Marital status & 0.004 & 0.011 & 0.354 \\
Education & 0.049 & 0.021 & $2.348^{* *}$ \\
Household size & -0.003 & 0.008 & 0.336 \\
Income & $-7.750 \mathrm{e}-08$ & 0.000 & -0.619 \\
Effect of real income $\left(\beta_{\mathrm{i}}\right)$ & 0.047 & 0.011 & $4.203^{\star * *}$ \\
Weighted unit price of fatty food $\left(\mathrm{Y}_{\mathrm{ij}}\right)$ & 0.173 & 0.045 & $3.833^{\star * *}$ \\
$\mathrm{R}^{2}$ & 0.669 & & \\
F statistics & $5.302^{* * *}$ & & \\
\hline
\end{tabular}

** and ${ }^{* * *}$ represent 5 and $1 \%$ levels of significance; Source: Results from LA/AIDS model.

Table 5. Household expenditure elasticity for food classes.

\begin{tabular}{lc}
\hline Food subgroup & Elasticity \\
\hline Starchy & 0.117 \\
Animal protein & 0.987 \\
Plant protein & 1.207 \\
Fat and oil & 2.042 \\
\hline
\end{tabular}

Source: Field Study (2010).

Table 6. Household own- price elasticities for food classes.

\begin{tabular}{lc}
\hline Food sub-group & Elasticity \\
\hline Starchy & -1.047 \\
Animal protein & -1.002 \\
Plant protein & -0.991 \\
Fat and oil & -1.048 \\
\hline
\end{tabular}

Source: Field Study (2010).

that education of the household head is a positive determinant of the proportion of the share of household budget spent on fatty food.

\section{Estimation of elasticity}

\section{Expenditure elasticity}

The expenditure elasticity can be interpreted as the percentage change in quantity demanded of a group of commodity when income changes by one percent holding every other variable constant. The expenditure elasticity is often used to categorize commodities into luxury and necessity. A commodity is considered luxury if the expenditure elasticity is greater than one, and necessity if unity or less than unity. The coefficient of expenditure elasticity is always positive. Expenditure elasticity for starchy, animal protein, plant protein and fat food subgroup are presented in Table 5. Expenditure elasticities for plant protein (1.207) and fatty food (2.042) are greater than one, indicating that they can be considered luxury goods. Although the expenditure elasticity for animal protein (0.987) is less than one, it is close enough to one, which is the cut-off point between luxury and necessary products. The relative low expenditure elasticity of starchy food (0.117) indicates that starchy food can be considered as one of the most necessity food items in this study area. The results reveal that $10 \%$ increase in the respondent's income would lead to $20.42,12.70,9.87$ and $1.17 \%$ increase in the demand of fatty food, plant protein food, animal protein and starchy food respectively. The result for starchy food items confirms Bennett's law which states that starchy staple' share of the budget tends to decline as household income increase, and vice versa.

\section{Own-price elasticity of demand}

Own price elasticity measures the degree of responsiveness of the budget share allocated to various food sub-groups as their respective prices change. The own -price elasticities for starchy, animal protein, plant protein and fatty food sub-groups are presented in Table 6. The own-price elasticities for starchy food (1.407), animal protein (1.002) and fatty food (1.048) are greater than one, implying that their prices have elastic relationship with their quantities demanded. On the other hand, the elasticity of plant protein (0.991) is less than unity, indicating inelastic relationship. The negative signs on the elasticity coefficients are indicative that as the prices of the respective food sub-groups increased the relative share (in percentage) of food expenditure decreased more than proportionately for each of the food sub- 
Table 7. Household cross-price elasticity for food classes.

\begin{tabular}{lcccc}
\hline Food classes & Starchy & Animal protein & Plant protein & Fat and oil \\
\hline Starchy & 0.000 & 0.001 & -0.009 & -0.044 \\
Animal protein & 0.176 & 0.000 & -0.003 & -0.031 \\
Plant protein & 0.048 & 0.001 & 0.000 & -0.008 \\
Fat and oil & 0.048 & 0.001 & -0.009 & 0.000 \\
\hline
\end{tabular}

Source: Field Study (2010).

groups in this study area. For instance, $10 \%$ increase in the price of starchy food, animal protein, plant protein and fatty food items would lead to 10.47, 10.02, 9.91 and $10.48 \%$ reduction in the demand of the respective food items. However, the result satisfies a priori theoretical expectation and is consistent with the Engel's finding which says that the price elasticity coefficient is normally negative.

\section{Cross-price elasticity of demand}

Cross-price elasticity is the degree of responsiveness of the share of total food budget allocated to a particular food sub-group as a result of changes in the prices of other food sub-groups. The cross-price elasticities for the different food sub-groups are presented in Table 7.

The findings revealed that the relationship among some sub-groups were negative, showing the presence of the substitutability characteristics of this groups. For instance, plant protein and animal protein have crossprice coefficient of -0.003 . This implies that, $10 \%$ increase in the price of animal protein would result in $0.03 \%$ increase in the demand for plant protein. Similarly, $10 \%$ increase in the price of fatty food would lead to $0.44 \%$ increase in the demand of starchy food. The findings also revealed that some sub-groups had positive relationship among them, implying the existence of complementarity in the sub groups. For instance, a $10 \%$ increase in the prices of animal protein would cause about $17.60 \%$ increases in the demand for starch food and vice versa. Similarly, $100 \%$ increase in the price of starchy food would result in $4.80 \%$ increase in demand of plant protein and fatty foods respectively.

\section{CONCLUSION AND RECOMMENDATIONS}

This study fitted LA/AIDS model using panel data derived from households in Uyo metropolis. The model results provide statistical estimates and prove the theoretical expectation regarding the demand for certain food type in this study area. For instance, the expenditure elasticities of all food classes have positive signs, implying that as income increases, food demand will increase too. Also all food classes had negative own-price elasticities of demand, which implying that they satisfy a priori demand theory and are thus normal goods. Furthermore, the estimates of the cross-price elasticity reveal that the food sub groups studied have both positive and negative signs implying that some food types are complementary while others are substitutes. Based on results of these findings, we recommended that policies to increase the income and improved working conditions of the households in this study area should be formulated so as to enhance their purchasing power. Government should also formulate policies that help to stabilize food prices so as to enhance household's minimum daily food requirement and encourage appropriate consumption of different food classes.

\section{REFERENCES}

Abdulai A, Jain DK (1999). Using micro level data to analyze consumption of milk and milk products in India, Quar. J. I. Agric. 38: 53-64.

Adejobi AO, Alemu T, Oluwasola O (2009). Demand elasticities for the poor and non-poor households in rural Nigeria: An application of LA/AIDS model. J. Agric, Food. Environ. 5(1):44-51

Akintola JO, Udoh EJ (2002). An analysis of beef demand in Nigerian urban city. Glo J. Pure. Appl. Sci. 9(1):1-12

Balcombe K, Rapsomanikis G, Klonaris S (2003). Cross entropy estimation of the Almost Ideal Demand System for Greek consumption. J. Agric. Econ. 54:447-466

Barnett WA, Seek O (2008). Rotherdam model and almost ideal demand system: will the best specification please stand up. J. Appl. Econ. 23:795-824

Blanciforti LA, Green RD, King GA (1986). US consumer behavior over the postwar period: An almost ideal demand analysis, Giannini Foundation Monograph, No. 40, University of California, Davis.

Deaton A , Muellbauer J (1980). An Almost Ideal Demand System. Am. Econ. Rev. 70:312-336.

Eales JS, Unnevehr LJ (1988). Demand for beef and chicken products: separability and structural change. Am. J. Agric. Econ. 70: 521-532.

FAO, (1980). Production Year Book. p. 34, Rome.

Glewwe P (2001). Lecture notes, Consumption Economics- APEC 8401. University of Minnesota, St. Paul.

Jabarin AS, Al-Karablieh EK (2011). Estimating the Fresh Vegetables Demand System in Jordan: A Linear Approximate Almost Ideal Demand System. J. Agric. Sci. Tech. 5(3 (Serial No.34):322-331

Jeffry S, Brown J (2008). A demand analysis of the UK canned tuna market, Marine Res. Econ. 23:215-227.

National Population Commission (2006). National Population Census 2006.

Sasaki K (1993). The structure of food demand in Japan: An Application of the Rotterdam System. Agribus. J. 9(5):425-439

Taljaard PK, Alemu AG, Van Schallwyk HD (2003). A Linearized Almost Ideal Demand System (LA/AIDS) Estimation of the Demand for Meat in South Africa." Contributed Paper Presented at the 4th Annual Conference of the Agricultural Economics Association of South Africa (AEASA), October 2-3. pp. 1-11. 
Wessells CR, Eales J, Durham C (1997). Generalized model of Japanese demand for fish, Am. J. Agric. Econ. 79(4):1153-1163 